\title{
FACTORING AGREEMENT - INSTRUMENT FOR CREDIT INSTITUTIONS
}

\author{
C. M. Paraschiv
}

\section{Cristina Marilena Paraschiv}

Faculty of Administration and Business, Department of Economics and Administrative Sciences, University of Bucharest, Bucharest, Romania

*Correspondence: University of Bucharest, no. 4-12, Regina Elisabeta Blv., sector 1, Bucharest, Romania

E-mail: av_cristina.paraschiv@yahoo.com

\begin{abstract}
The Factoring agreement as operational instrument of credit institutions is of special importance due to its permanent applicability, with the effect of streamlining the commercial activities, both at national and international level. This contract represents a financial technique closely related to the banking sector, and it can be considered as a variety of the bank credit.
\end{abstract}

Key words: factoring, banking practice, contract, adherent, cession;

\section{Introduction}

Taking into consideration more than succinct regulation regarding the factoring contract at the national level, it is still considered an unnamed contract ${ }^{1}$. Within the Romanian legislation the factoring agreement was first mentioned by GEO no. 10/1997 on decreasing financial blockage and losses in the economy ${ }^{2}$, for subsequently to be regulated by Law no. 469/2002, currently abrogated. Internationally the factoring agreement is regulated by UNIDROIT Convention on International Factoring agreement from Ottawa in 1988, the Rome Convention of 1980 on the law applicable to contractual obligations as well as the United Nations Convention in New York in 2001 on the assignment of receivables in international trade.

\section{The concept, the legal nature and the parties of factoring agreement}

The concept of factoring has its origins in the $17^{\text {th }}$ century, in the Anglo-Saxon Law, and it played a significant role in the development of international trade, at the time of its appearance being concentrated in the textile trade between England and the United States.

In French doctrine ${ }^{3}$ factoring is considered a technique by means of which a customer called adherent or supplier submits his receivables to a factoring company called factor which is a credit institution subject to the rules of Monetary and Financial Code. In return for remuneration, the factor undertakes to collect the adherent's receivables from its debtors and to pay in advance, in whole or in part, the receivables transferred, ensuring the enforcement of receivables even if the debtor cannot pay.

Within the Romanian legislation the factoring agreement was defined as that "agreement concluded between a party called adherent, supplying goods or providing services, and a banking company or specialized financial institution, called factor, by means

\footnotetext{
${ }^{1}$ Brânduşa Vartolomei, Contractul de factoring, Lumina Lex Publishing House, Bucharest, 2006, p. 40-41.

${ }^{2}$ Official Gazette of Romania. no. 72/22.04.1997, abrogated by art. 13 of Law no. 469/2002, in its turn abrogated by Law no. 246/2009 published in the Official Gazette of Romania no. 450/30.06.2009.

${ }^{3}$ Lavinia Smarandache, Alina Dodocioiu, Considerații privind contractul de factoring, Revista de ştiințe juridice Publishing House, no. 4/2008, p. 98 apud T. Bonneau, Droit bancaire, Montchrestien, Paris, 2003, p. 373.
} 
of which the latter shall ensure the financing, receivables monitoring and the protection against credit risks, and the adherent assigns to the factor, by way of sale, the receivables arising from the selling of goods or provision of services to third parties". 4

In the Romanian literature ${ }^{5}$ as well, the factoring agreement is considered to be that contract whereby a party called adherent assigns its receivables against its customers to the other party called factor, which in the exchange of a certain commission, undertakes to pay to the adherent the value of these receivables which it is to collect from the debtors taken over, therefore being subrogated to the rights the adherent had against its customers

In most European countries the factoring agreement is regulated starting from the institution of assignment of receivables that has many similarities with regarding the receivables transmission. Although as legal nature this contract has similarities with receivables assignment, it cannot be mistaken with this civil law institution, as it is a contract concluded between professionals, an original and complex contract. In addition it is an adhesion contract that is concluded intuitu personae. On the other hand, in France the factoring agreement is much closer regulated by the contractual subrogation consented by the creditor, but it cannot be confused with this institution, as it cannot be confused as well with the operation of discount or credit insurance.

Taking into consideration the definitions existing in the literature at the national and international level, the parties of the factoring agreement are: the adherent, the factor and the assigned debtor.

The adherent is always a good supplier, a services provider or a contractor, in other words it is a natural or legal person professional. There are points of view in the literature considering that the status of adherent could be acquired by legal persons as well, other than professionals, to whom the legislation in force allows to develop accessory nature commercial activities and closely related to the main purpose of that legal person. This category is considered to contain autonomous ${ }^{6}$ administrations or the associations, foundations and federations ${ }^{7}$.

If in terms of the adherent we have shown that it can be a natural or legal person professional and, according to some opinions, even an unprofessional, in what concerns the factor, it is a legal qualified subject. The factor can only be a specialized financial institution or a banking company that is a legal person.

The assigned debtor, although it is a participant within the factoring operation itself, it is not part of the factoring agreement. Nevertheless, certain effects of the factoring agreement are reflected on its own person, as we will show in the following.

By the conclusion of the factoring agreement, the payment liability of the assigned debtor is transferred from the adherent to the factoring company, the debtor being forced to pay all the amounts recorded in the invoices only to the factoring company. The payment shall be made starting from the date the receivables become due. In case the debtor refuses to make the payment, even though it is not part of the factoring contract it can be directly taken to court by the factor and, consequently, in its turn, it will be able to defend itself by invoking all the exceptions and defenses that it would have had available against the adherent. In its defense, the assigned debtor may oppose to the factor including the exception to limitation of actions, to extinguish the debt by payment, prior to the notification, or compensation, occurring previously to the receivables assignment ${ }^{8}$.

\footnotetext{
${ }^{4}$ Art. 6 par. (2) letter b) of Law no. 469/2002.

5 B. $\square$ tefănescu, I. Rucăreanu, Dreptul comerțului internațional, Didactică şi Pedagogică Publishing House, Bucharest, 1983, p. 231.

${ }^{6}$ Brânduşa Vartolomei, op. cit., p. 49.

${ }^{7}$ See art. 48 of GO no. 26/2000 regarding associations and foundations, published in the Official Gazette of Romania no. 39/31.01.2000, with all subsequent amendments and completions.

${ }^{8}$ L. Stănciulescu, V. Nemeş, Dreptul contractelor civile şi comerciale în reglementarea noului Cod civil, Hamangiu Publishing House, Bucharest 2013, p. 619.
} 


\section{Types of factoring agreement}

Several criteria are used in order to classify factoring types.

Therefore, depending on the time the factor pays the adherent the receivables incorporated in the invoices, the factoring agreement may be classified in:

a. Old line factoring - which is characterized by the fact that the receivables payment is performed by the factor upon receipt thereof, that means before their maturity date;

b. Maturity factoring - when the factor shall pay the adherent the assigned receivables only at their maturity; the risk of default of invoices payment by the assigned debtors as well as the invoices management are transferred to the factor person;

c. Agency factoring -when the factor buys the adherent's receivables and, after their acceptance he pays them in advance, taking over the risk of the debtors' default of payment. The difference is the fact that the invoices management remains to the adherent who will take care of collecting invoices in its own name, submitting afterwards the collected amounts to the factor.

Depending on the right of recourse ${ }^{9}$ the bank may have on the adherent:

a. Factoring with recourse - the risk of insolvency or the refusal to pay the debts by the assigned debtor belongs to the adherent;

b. Non-recourse factoring - the risk of payment default or insolvency of the assigned debtor passes to the factor at the same time with his obtaining the debts from the adherent;

Taking into account the participants to the factoring operation ${ }^{10}$ :

a. Domestic factoring - when the factoring operation is carried out within the territory of a single state, with a single factor intervention;

b. External factoring - when we are in the situation of an international commercial contract, in the factoring operation taking place the intervention of 2 factors: an export factor and an import factor;

\section{Object and specific clauses of the factoring agreement}

The object of the factoring agreement is a special one consisting in financing, monitoring and protection against the credit risks by the factor, obtaining in exchange the receivables from the adherent ${ }^{11}$. An essential condition is the fact that, in order to be the object of a factoring agreement, the receivables must be clear and liquid and have expressly stated the due date or at least to have the possibility to determine it. Including future receivables may be the object of a factoring agreement. The assigned receivable may rise only from a commercial act and it shall be expressed by a specific title - the invoice.

Given the risk taken over by the factor when accepting the adherent's receivables, there are two clauses specific to the factoring agreement:

a. Exclusivity clause - by which the adherent is required to submit only to the factor all the invoices including the receivables on the debtors. In this situation, the factor has the possibility that of all the invoices submitted by the adherent to choose only those that present the lowest risk of not being paid at maturity by the assigned debtor;

b. The global clause - by which the adherent transfers to the factor all its invoices in order to prevent the possibility of being tempted to assign the factor only the invoices with an increased risk of not being collected, and keep to himself the certain receivables, easily to be recovered.

Functions of the factoring agreement

\footnotetext{
${ }^{9}$ L. Stănciulescu, V. Nemeş, op. cit., p. 612.

${ }^{10}$ Lavinia Smarandache, Alina Dodocioiu, op. cit., p. 101.

${ }^{11}$ L. Stănciulescu, V. Nemeş, op. cit., p. 615.
} 
Starting from the tripartite relationship arising under the factoring agreement and taking into consideration the literature at the national and international level, we can conclude that the most important functions of the factoring agreement are the following ${ }^{12}$ :

1. Financing function - also called liquidity function.

By the factoring agreement, the factor provides a financial service to the adherent for which it does not require guarantees, the guarantee function being completed by the transferred receivables. Therefore, the factor, under the conditions of taking over the receivables from the adherent, shall provide him with the necessary liquidity. Therefore, the adherent benefits from liquidity before the moment its receivables would have reached maturity. It should be mentioned the fact that this type of financing is made for a short period of time, of 90 to a maximum 120 days, and only exceptionally 180 days.

This type of financing represents a special category as it consists in an exchange of actual assets, receivables being converted into financial obligations.

2. Services function - also called service provision function or management function.

During the performance of the factoring agreement, depending on the type of factoring chosen, the factor can provide in favor of the adherent a complex package of services, such as:

- Checking the creditworthiness situation of the debtors;

- The debtors' record and accounting, with all the necessary data regarding the receivables records;

- Monitoring the solvency degree of the debtors taken over;

- Invoicing responsibilities;

- Receivables collection responsibilities;

- Consultancy regarding the activity of debts liquidation;

- Consultancy having as its object the accounting and financial management;

- Consultancy regarding the factoring business in tax issues;

This function is of particular importance within the factoring process, relieving the adherent of certain activities and costs that are taken over by the factor, the adherent being able to exclusively focus on the manufacturing or services provision activity. It basically occurs an outsourcing of the aforementioned services, noting that the enumeration is not exhaustive.

3. Del credere function - also called the credit risk assuming

By the del credere function the factor takes over the credit risk from the time of receivables purchase. Basically this function requires the action of taking over by the factor of the creditworthiness risk of assigned receivables, after a prior verification of the credibility and ability to pay of the debtor, verification performed by the factor. This means that, after signing the factoring agreement, the factor shall no longer be able to invoke the action of recourse against the adherent in case of insolvency or any default of payment of the assigned debtor.

\section{Conclusions}

Taking into consideration the current economic situation as well as the fact that banks granting loans is increasingly difficult and the capital market moves with difficulty, in this context, on the national and international transactions market, as well as in European companies development and financing, factoring becomes the most available tool, representing the only financing source through which the financing increases at the same time with the sales, being also the cheapest form of short-term financing.

Given the fact that factoring is a financial product of financing without guarantees but also a highly complex commercial management product, this type of contract can represent

\footnotetext{
${ }^{12}$ See Cosmina Petre, Factoringul, o alternativă modernă de finanțare a întreprinderilor europene, Danubius Proceedings, Volume II, 2007, p. 568.
} 
the saving solution for the companies that cannot support themselves from the financial point of view, but that have a well-developed business plan.

\section{Bibliography:}

L. Stănciulescu, V. Nemeş, Dreptul contractelor civile şi comerciale în reglementarea noului Cod civil, "Hamangiu" Publishing House, Bucharest, 2013;

Lavinia Smarandache, Alina Dodocioiu, Considerații privind contractul de factoring, "Revista de ştiințe juridice" Publishing House no. 4/2008;

Cosmina Petre, Factoringul, o alternativă modernă de finanțare a întreprinderilor europene, Danubius Proceedings, Volume II, 2007;

Brânduşa Vartolomei, Contractul de factoring, "Lumina Lex" Publishing House, Bucharest, 2006;

T. Bonneau, Droit bancaire, Montchrestien, Paris, 2003;

Brânduşa. Ştefănescu, I. Rucăreanu, Dreptul comerțului internațional, "Didactică şi Pedagogică” Publishing House, Bucharest, 1983. 